\title{
PERKEMBANGAN KINERJA KEUANGAN PT PERTAMINA (Persero)
}

\section{JAKARTA}

\author{
Tutik Wiryanti ${ }^{1}$ dan Bambang B. Sulistiyono ${ }^{2}$
}

\begin{abstract}
PT Pertamina (Persero) is a State-owned Enterprise (SOE) whose shares are not listed on the stock exchange, so the Company does not present information about the stock price,number of outstanding shares, market capitalization, highest and lowest price, closing price, and trading volume.The share holder owned 100\% by Government of the Republic of Indonesia, the company's shares are not to be traded.

Pertamina improved its performance based on the strategy of "aggressive upstream, profitable downstream." As a world-class company, Pertamina transformed challenges into opportunities. Pertamina maximized efficiency and optimized production. On the other hand, the optimized performance was enhanced in line with strengthening the performance of good corporate governance (GCG).The rise in crude oil production and the acquisition of Murphy Oil Corp.assets in Malaysia was one of the good achievements in 2014.

In general, Pertamina's financial performance, financial ratios and operational

performance were quite satisfactory, although some achievements did not meet expectations. Its performance and achievements, Pertamina will move faster. The theme of "Inspiring Indonesia to the World" in Annual Report 2014 was chosen to convey the moving-forward of global energy issues and to inspire others as an energy provider.
\end{abstract}

Keywords : Financial Performance, Development

\section{PENDAHULUAN}

PT Pertamina (Persero) Jakarta merupakan Badan Usaha Milik Negara (BUMN) yang tidak memperdagangkan sahamnya di bursa efek sehingga tidak memiliki informasi harga saham, jumlah saham yang beredar, kapitalisasi pasar, harga saham tertinggi dan terendah, harga saham penutupan dan volume perdagangan saham. Pemegang Saham PT Pertamina (Persero) 100\% dimiliki oleh Pemerintah Republik Indonesia dan saham perusahaan tidak

\footnotetext{
1.t.wiryanti01@gmail.com
}

2bangsul76@gmail.com diperdagang-kan. Sebelum menjadi PT Pertamina (Persero), pada awalnya sekitar tahun 1950an Pemerintah Republik Indonesia menunjuk Angkatan Darat yang mendirikan PT Eksploitasi Tambang Minyak Sumatera Utara untuk mengelola ladang minyak di wilayah Sumatera. Pada tanggal 10Desember 1957, perusahaan tersebut berubah nama menjadi PT Perusahaan Minyak Nasional disingkat PERMINA dan tanggal itu diperingati sebagai lahirnya PERTAMINA sampai saat ini. Pada tanggl 1 Juli 1961, PT 
Permina berubah menjadi PN Permina.Tanggal 20 Agustus 1968 PN Permina dan PN Pertamina dilebur menjadi PN Pertamina. Berdasarkan UU No.8 Tahun 1971 pada tanggal 15 Desember 1971, pemerintah mengendalikan langsung dan mengatur peran PN Pertamina untuk menghasilkan dan mengelola migas dari ladang-ladang minyak serta menyediakan kebutuhan bahan bakar gas di Indonesia. Pemberlakuan UU migas melalui UU No. 22 Tahun 2001, merubah tata kelola migas di Indonesia, sehingga peran Pertamina tidak lagi sebagai regulator, sehingga penyelenggara Public Service Obligation (PSO) dilakukan melalui kegiatan usaha. Berdasarkan UU No. 19 Tahun 2003 Tanggal 17 September 2003 Pertamina resmi menjadi PT Pertamina (Persero) yang melakukan kegiatan usaha migas pada sektor hulu dan sektor hilir. Pada tanggal 10 Desember 2005 PT Pertamina (Persero) berganti logo yang semula berlambang kuda laut menjadi anak panah yang warna dasar hijau, biru dan merah yang merefleksikan unsur dinamis dan kepedulian lingkungan.Tanggal 10 Desember 2007

PT Pertamina (Persero) menetapkan visi yang baru untuk "Menjadi Perusahaan Minyak Nasional Kelas Dunia”. Pada tanggal 14 Juni 2011 menyempurnakan visi baru "Menjadi Perusahaan Energi Nasional Kelas Dunia”. Tanggal 9 Juli 2012 dalam Rapat Umum Pemegang Saham Luar Biasa (RUPSLB) menyetujui Perubahan
Anggaran Dasar Pertamina dalam hal perluasan bidang usaha Pertamina di bidang penyelenggaraan energi, energi baru dan terbarukan

\section{PEMBAHASAN}

Pembahasan ini akan menguraikan tentang visi dan misi Perusahaan, tujuan, tata nilai unggulan $6 \mathrm{C}$, keunggulan perusahaan, bidang usaha, produk dan jasa, unit kerja, sertifikasi (unit operasi, unit bisnis dan lainnya), perkembangan kinerja operasional dan kinerja keuangan PT Pertamina (Persero) Jakarta selama tahun 2009 - 2014. Jumlah Aset PT Pertamina (Persero) per Desember 2014 sebesar US\$ 50.328 juta. Modal Dasar per Desember 2014 yaitu Rp. 200.000.000.000.000,- (dua ratus triliun rupiah), terdiri dari 200.000.000 lembar saham dengan nilai nominal Rp. 1.000.000,(satu juta rupiah) per lembar saham. Modal ditempatkan per 31 Desember 2014 yaitu Rp.83.090.697.000.000,- (delapan puluh tiga triliun sembilan puluh miliar enam ratus sembilan puluh tujuh juta rupiah), terdiri dari 83.090.697 lembar saham dengan nilai nominal Rp.1.000.000,- (satu juta rupiah) per lembar saham.

\section{Visi dan Misi Pertamina :}

Visi : Menjadi Perusahaan Energi Nasional Kelas Dunia.

Misi : Menjalankan usaha Minyak, Gas serta Energi Baru dan Terbarukan secara terintegrasi, berdasarkan prinsip-prinsip komersial yang kuat. 


\section{Tujuan Perusahaan :}

1. Melakukan usaha energi, yaitu minyak dan gas bumi, energi baru dan terbarukan, baik di dalam negeri maupun di luar negeri serta kegiatan lain yang terkait atau menunjang kegiatan usaha di bidang energi yaitu minyak dan gas bumi, energi baru dan terbarukan.

2. Pengembangan optimalisasi sumber daya yang dimiliki Perseroan untuk menghasilkan barang dan atau jasa yang yang bermutu tinggi dan berdaya saing kuat.

3. Meraih keuntungan guna meningkatkan nilai perseroaan dengan menerapkan prinsip-prinsip Perseroan Terbatas.

\section{Tata Nilai Unggulan 6 C :}

Untuk mewujudkan Visi dan Misi Perusahaan berdasarkan standar global dan penerapan tata kelola, perusahaan memiliki tata nilai sebagai komitmennya berikut ini :

\section{a. Clean (Bersih)}

Dikelola secara profesional, menghindari benturan kepentingan, tidak menoleransi suap, menjunjung tinggi kepercayaan dan integritas, berpedoman pada asas-asas tata kelola korporasi yang baik.

\section{b. Competitive (Kompetitif)}

Mampu berkompetisi dalam skala regional maupun internasional, mendorong pertumbuhan investasi, membangun budaya sadar biaya dan menghargai kinerja.

\section{c. Confident (Percaya Diri)}

Berperan dalam pembangunan ekonomi nasional, menjadi pelopor dalam reformasi Badan Usaha Milik Negara (BUMN) dan membangun kebanggaan bangsa.

d. Customer Focus (Fofus pada Pelanggan)

Berorientasi pada kepentingan pelanggan dan berkomitmen untuk memberikan pelayanan terbaik kepada pelanggan.

e. Commercial(Komersial)

Menciptakan nilai tambah dengan orientasi komersial, mengambil keputusan berdasarkan prinsip-prinsip bisnis yang sehat.

\section{f. Capable(Berkemampuan)}

Dikelola oleh pemimpin dan pekerja yang profesional yang memiliki talenta dan penguasaan teknis tinggi, berkomitmen dalam membangun kemampuan riset dan pengembangan.

\section{Keunggulan Pertamimna sebagai}

\section{Perusahaan Energi Nasional Kelas Dunia,} yaitu:

1. Mengoperasikan bisnis yang terintegrasi dari hulu hingga hilir, menjadikan Pertamina sebagai Perusahaan yang mampu menghadapi persaingan kelas dunia

2. Memiliki wilayah operasi blok migas internasional diAsia Tenggara, Afrika, dan Timur Tengah 
3. Melakukan inovasi Pertamina tanpa henti, yang dibuktikan melalui Continuous Improvement Program (CIP) dengan value creation $\mathrm{Rp} 8$ triliun tahun 2014

4. Mengembangkan teknologi eksplorasi, produksi minyak dan gas serta panas bumi sesuai kondisi geologis, topografi dan sosial Indonesia, dengan melibatkan perguruan tinggi

5. Memenuhi standar kelas dunia, yang dibuktikan dengan mengurangi drilling time dan rig moving, pengeboran lebih cepat 311 hari dari yang ditargetkan di lapangan Banyu Urip, Blok Cepu

6. Memiliki kemampuan meningkatkan produksi migas sebesar 3\% di Indonesia untuk periode 2010-2013 ketika operator lain mengalami penurunan

7. Menjaga keseimbangan ekonomi, sosial dan lingkungan, yang diwujudkan dengan memperoleh 4 PROPER Emas dan 42 PROPER Hijau tahun 2014, dari Kementerian Lingkungan Hidup dan Kehutanan, serta penghargaan dalam dan luar negeri

8. Memiliki infrastruktur dan jaringan distribusi memadai dan terintegrasi, didukung oleh 8 Marketing Operation Region, 557 unit Stasiun Pengisian Bulk Elpiji, 62 unit Depot Pengisian Pesawat Udara, 21 unit Terminal LPG, 3 unit LOBP, 109 unit Terminal BBM, 5.155 unit SPBU, 25 unit SPBG, 1.624 unit jalur Pipa Gas, 192 unit Kapal Tanker, 14 unit STS, 135 Terminal Khusus, 214 Dermaga, 19 unit SPM, 12 unit CBM dan 6 unit Pengolahan Menyediakan energi secara luas bagi kehidupan manusia dengan tetap berkontribusi positif terhadap planet bumi, seperti program pengurangan emisi $\mathrm{CO} 2$ dan program menabung 100 juta pohon sebagai bentuk kepedulian terhadap pemanasan global (global warming) dan kelestarian lingkungan

9. Memiliki kemampuan meningkatkan produksi migas sebesar 3\% di Indonesia untuk periode 2010-2013 ketika operator lain mengalami penurunan.

10. Mengoperasikan Very Large Gas Carrier (VLGC) terbesar di dunia, yaitu Pertamina Gas 1 dan Pertamina Gas 2 dengan kapasitas masing-masing 84.000CuM.

\section{Bidang Usaha, Produk dan Jasa}

Menurut Anggaran Dasar yang terakhir, pasal 3 yang direvisi sesuai Akta Pernyataan Keputusan Rapat Umum Pemegang Saham PT Pertamina (Persero) No. 01 tanggal 1 Agustus 2012 bahwa kegiatan usaha perusahaan adalah melakukan usaha di bidang penyelenggaraan usaha energi meliputi minyak dan gas bumi, energi baru dan terbarukan serta kegiatan lain yang terkait atau menunjang kegiatan usaha di bidang energi. Kegiatan usaha yang dijalankan Pertamina saat ini terbagi atas 
sektor hulu, sektor gas, energi baru dan terbarukan, sektor pengolahan dan sektor pemasaran. Selain itu, Pertamina juga menjalankan kegiatan usaha lain seperti jasa konsultan, transportasi, rumah sakit dan properti.

\section{a. Sektor Hulu}

Sektor Hulu Pertamina terdiri dari kegiatan eksplorasi, pengembangan dan produksi minyak dan gas.Kegiatan usaha lainnya pada sektor hulu adalah jasa teknologi bidang hulu, jasa pengeboran, pengembangan energi panas bumi dan Gas Metana Batubara (GMB) seta Shale Gas.

\section{b. Sektor Energi Baru dan Terbarukan}

Sektor energi baru dan terbarukan Pertamina membawahi kegiatan usaha gas, energi baru dan terbarukan secara terintegrasi dari hulu (komersialisasi gas, tidak termasuk eksplorasi dan produksi gas) hingga ke hilir.

\section{c. Sektor Pengolahan}

Pada sektor pengolahan, Pertamina menjalankan kegiatan usaha di dalam dan di luar negeri yang antara lain mencakup pengolahan, pengelolaan pabrik, petro kimia, kilang LNG, regasifikasi LNG serta pengapalan LNG. Selain itu, Pertamina juga mengelola pembangkit listrik panas bumi.

\section{d. Sektor Pemasaran}

Pada bagian hilir, Pertamina melakukan usaha pemasaran, perdagangan dan distribusi bebagai jenis produk seperti bahan bakar minyak (BBM), pelumas, gas, produk petro kimia serta produkproduk non BBM lainnya untuk pasar domestik dan mancanegara.

\section{Unit Kerja PT Pertamina (Persero) Tahun}

2014

- 6 unit Pengolahan

- 8 Marketing Operation Region

- 557 unit Stasiun Pengisian Bulk Elpiji

- 62 unit Depot Pengisian Pesawat Udara (DPPU)

- 21 unit Terminl LPG

- 3 unit Lube Oil Blending Plant (LOBP)

- 109 unit Terminal BBM

- 1.624 unit Jalur Pipa Gas

- 192 unit Kapa Tanker (64 kapal milik sendiri) dan lainnya sewa

- 5.155 unit Stasiun Pengisian Bahan Bakar Umum (SPBU)

- 25 unit Stasiun Pengisian Bahan Bakar Gas (SPBG)

- 135 Terminal Khusus

- 214 Dermaga

- 19 unit SPM ( Single Point Mooring)

- 14 unit STS (Ship to Ship)

- 12 unit CBM (Central Buoy Mooring)

- 23 Anak Perusahaan

- 6 Perusahaan Asosiasi

- 7 Entitas Ventura Bersama

Sertifikasi(Unit Operasi, Unit Bisnis dan lainnya)

PT Pertamina (Persero) dalam menunjang kegiatan operasi dan bisnisnya sudah memiliki sertifikasi secara nasional maupun internasional sebagai berikut : 
Tabel

Sertifikasi (Unit Operasi, Unit Bisnis dan lainnya)

\begin{tabular}{|c|c|c|c|c|}
\hline No. & Unit Operasi/Unit Bisnis & Sertifikat & Tanggal Berlaku & Badan \\
\hline & & & & Sertifikasi \\
\hline \multirow[t]{2}{*}{1} & Operasi Pemasaran Wil VII & ISO 9001:2008, OHSAS 18001: & 8 Des 2011 - 8 Des 2014 & BSI \\
\hline & Sulawesi & 2007, ISO 14001:2004 & & BSI \\
\hline \multirow[t]{3}{*}{2} & Operasi Pemasaran Wil. II & ISO 9001:2008 & 8 Des 2013 - 8 Des 2016 & $\mathrm{BSI}$ \\
\hline & Sumatera Selatan & OHSAS 18001: 2007 & 23 Maret $2013-21-03-2016$ & BSI \\
\hline & & ISO 14001:2004 & 29 Nop 2014-29 Nop 2017 & BSI \\
\hline \multirow[t]{3}{*}{3} & Operasi Pemasaran Wil. I & ISO $9001: 2008$ & 1 Des 2013 - 30 Nop 2016 & $\mathrm{BSI}$ \\
\hline & Sumatera Utara & OHSAS 18001:2007 & 23 Maret $2013-21-03-2016$ & BSI \\
\hline & & ISO 14001:2004 & 26 Juli 2012 - 26 Juli 2015 & $\mathrm{BSI}$ \\
\hline 4 & DPPU Ngurah Rai & ISO 5001:2011 & 3 Juli 2014 - 3 Juli 2017 & $\mathrm{BSI}$ \\
\hline 5 & TBBM Rewulu Yogyakarta & ISO 5001:2011 & 26 Maret 2014 - 26-03-2017 & BSI \\
\hline \multirow[t]{2}{*}{6} & Refinery Unit VI - Balongan & ISO 9001:2008, OHSAS 18001: & 22 Maret 2012 - 26-03-2015 & SGS \\
\hline & & 2007, ISO 14001:2004 & & \\
\hline \multirow[t]{2}{*}{7} & Refinery Unit V-Balikpapan & ISO 9001:2008, OHSAS 18001: & Sept 2012 - Sept 2015 & TUV \\
\hline & & 2007, ISO 14001:2004 & & Rhienlan \\
\hline \multirow[t]{2}{*}{8} & Refinery Unit IV - Cilacap & ISO 9001:2008, OHSAS 18001: & Oktober 2012 - Oktober 2015 & TUV \\
\hline & & 2007, ISO 14001:2004 & & Rhienlan \\
\hline \multirow[t]{2}{*}{9} & Refinery Unit IV - Plaju & ISO 9001:2008, OHSAS 18001:2007 & 16 Januari 2013 - 16-01-2016 & TUV Nord \\
\hline & & ISO 14001:2004, ISO 17025:2005 & 14 Juni 2012 - 14 Juni 2015 & TUV Nord \\
\hline \multirow[t]{2}{*}{10} & Refinery Unit IV - Dumai & ISO 9001:2008, OHSAS 18001:2007 & 16 Januari 2013 - 16-01-2016 & TUV Nord, \\
\hline & & ISO 14001:2004, ISO 17025:2005 & & KAN \\
\hline \multirow[t]{2}{*}{11} & PT Pertamina (Persero) & ISO/IEC 2000.1:2011 & 29 Oktober 2014 & TUV SUDPSB \\
\hline & Corporate Shared Service & & & PteLtd Spore \\
\hline \multirow[t]{2}{*}{12} & PT Pertamina (Persero) & ISO/IEC 27001:2005 & 7 Nopember 2014 & TUV SUDPSB \\
\hline & Corporate Shared Service & & & Pteltd S'pore \\
\hline 13 & PT Pertamina (Persero) & DOC (Document of Compliance) IS & 23 Desember 2014 & BKI, NK Class \\
\hline 14 & PT Pertamina (Persero) & ISO 9001:2008 & 4 Des 2014 - 4 Des 2015 & LRQA \\
\hline
\end{tabular}

Sumber : Laporan Tahunan PT Pertamina (Persero) Tahun 2009 - 2014 


\section{Kinerja Operasional PT Pertamina (Persero)}

Ikhtisar Kinerja Operasional PT Pertamina (Persero) selama 6 tahun dapat dilihat pada tabel berikut ini :

\section{Tabel}

\section{Kinerja Operasional PT Pertamina (Persero) Tahun 2009 - 2014}

\begin{tabular}{|c|c|c|c|c|c|c|c|}
\hline Deskripsi & Satuan & 2014 & 2013 & 2012 & 2011 & 2010 & 2009 \\
\hline \multicolumn{8}{|l|}{ Minyak Mentah : } \\
\hline Temuan Cadangan Minyak, & MMBO & 129,39 & 102,04 & 108,70 & 343,34 & 62,806 & 61,43 \\
\hline Produksi Minyak Mentah & МMBO & 87,19 & 73,55 & 71,76 & 70,76 & 70,01 & 64,40 \\
\hline \multicolumn{8}{|l|}{ Gas Bumi : } \\
\hline Temuan Cadangan Gas Bumi & BSCFG & 973,18 & 783,73 & 964,10 & 769,54 & $1.644,50$ & $1.393,79$ \\
\hline Produksi Gas Bumi & BSCFG & 588,67 & 557,67 & 563,15 & 558,60 & 532,85 & 502,05 \\
\hline \multicolumn{8}{|c|}{ Panas Bumi, Produksi Uap Setara Listrik : } \\
\hline Operasi Sendiri Pertamina & GWh & $2.831,40$ & $2.961,85$ & $2.125,11$ & $2.006,08$ & $2.114,92$ & $2.089,74$ \\
\hline Kontrak Operasi Bersama & GWh & $6.941,59$ & $6.282,94$ & $7.081,20$ & $7.082,54$ & $6.983,39$ & $7.146,02$ \\
\hline \multicolumn{8}{|l|}{ Pengelolaan Kilang : } \\
\hline Peng. Minyak Mentah, Gas dll & Juta Barel & 314,42 & 314,03 & 308,12 & 308,80 & 314,40 & 331,17 \\
\hline Volume Produksi BBM (10 prodk) & Juta Barel & 241,16 & 239,04 & 238,76 & 237,04 & 235,79 & 249,87 \\
\hline Volume Produksi Non BBM & Juta Barel & 22,18 & 21,74 & 23,56 & 25,11 & 21,86 & 23,95 \\
\hline \multicolumn{8}{|l|}{ Distribusi \& Pemasaran } \\
\hline Penjualan BBM (10 produk) & Juta KL & 65,17 & 65,37 & 64,88 & 64,60 & 59,76 & 58,58 \\
\hline Penjualan Domestik Non BBM & Juta KL & 65,17 & 65,37 & 7,23 & 6,46 & 5,72 & 5,01 \\
\hline Ekspor Produk Kilang & Juta MT & 37,73 & 42,40 & 29,94 & 31,54 & 40,46 & 39,00 \\
\hline Impor Produk Kilang, Beli Dms & Juta Barel & 234,56 & 22,81 & 226,47 & 212,70 & 178,59 & 133,69 \\
\hline Penjualan LNG & Juta Barel & 632,63 & 662,00 & 650,32 & 813,71 & 965,34 & $1.009,12$ \\
\hline \multicolumn{8}{|c|}{ Sumber : Laporan Tahunan PT Pertamina (Persero) Tahun 2009 - 2014} \\
\hline & & & & & & & \\
\hline
\end{tabular}

Dengan adanya data tersebutbisa dianalisis mengenai pertumbuhan Kinerja Operasional PT Pertamina (Persero) mulai tahun 2009 - 2014 dan hasilnya berikut ini :

\section{Minyak Mentah}

\section{a. Temuan Cadangan Minyak dan Kondensat}

Selama tiga tahun (2010, 2011 dan 2014) terjadi peningkatan temuan cadangan minyak dan kondesat, tetapi selama dua tahun $(2012,2013)$ mengalami penurunan.Tahun 2010 temuan cadangan minyak dan kondensat mengalami peningkatan sebesar 2,23\% dibandingkan 2009, peningkatan temuan cadangan 
minyak dan kondensat pada tahun 2011 sebesar 446,72\% dibandingkan 2010, tetapi tahun 2012 mengalami penurunan temuannya sebesar 68,34\% dibandingkan 2011,tahun 2013 menurun temuannya sebesar 6,13\% dibandingkan 2012 dan tahun 2014 meningkat temuan cadangan minyak dan kondensat sebesar 26,80\% dibandingkan 2013.

\section{b. Produksi Minyak Mentah}

Mulai tahun 2010 - 2014 terjadi peningkatan produksi minyak mentah terus-menerus berikut ini: peningkatan produksi minyak mentah tahun 2010 sebesar $8,71 \%$ dibanding-kan 2009, pada tahun 2011 sedikit peningkatan produksinya sebesar $0,88 \%$ dibandingkan 2010, tahun 2012 masih sedikit peningkatan produksinya yaitu $1,60 \%$ dibandingkan 2011, tahun 2013 meningkat produksinya sebesar 2,49\% dibandingkan 2012 dan tahun 2014 peningkatan produksi minyak mentah yaitu $18,49 \%$ dibandingkan 2013.

\section{Gas Bumi}

\section{a. Temuan Cadangan Gas Bumi}

Temuan cadangan gas bumi meningkat selama tiga tahun (2010, 2012, 2014), tetapi menurun selama dua tahun (2011, 2013) seperti berikut ini. Tahun 2010 peningkatan temuan cadangan gas bumi sebesar $17,99 \%$ dibandingkan 2009, namun tahun 2011 mengalami penurunan temuannya sebesar 53,21\% dibandingkan 2010, tahun 2012 meningkat temuannya sebesar $25,28 \%$ dibandingkan 2011, tahun 2013 ada penurunan temuannya sebesar 18,71\% dibandingkan 2012 dan tahun 2014 meningkat temuan cadangan gas bumi sebesar $24,17 \%$ dibandingkan 2013.

\section{b. Produk Gas Bumi}

Produk gas bumi meningkat selama empat tahun (2010, 2011, 2012, 2014), namun terjadi penurunan pada tahun 2013.Terdapat peningkatan produk gas bumi pada tahun 2010 sebesar $6,1 \%$ dibandingkan 2009, peningkatan produksi gas bumi pada tahun 2011 sebesar 4,83\% dibandingkan 2010, tahun 2012 sedikit meningkat produksinya sebesar $0,81 \%$ dibandingkan 2011, tahun 2013 
sedikit menurun produksinya sebesar 0,97\% dibandingkan 2012 dan tahun 2014 meningkat produksi gas bumi yaitu $5,56 \%$ dibandingkan 2013.

\section{Panas Bumi Produksi Uap Setara} Listrik

Pada tahun 2010 dan 2011 terjadi penurunan panas bumi produksi uap setara listrik, tetapi tahun 2012

- 2014 mengalami peningkatan produksinya. Tahun 2010, panas bumi produksi uap setara listrik dalam produksinya menurun sebesar 1,47\% dibandingkan 2009, tahun 2011 sedikit menurun produksinya sebesar $0,11 \%$ dibandingkan 2010, tetapi tahun 2012 meningkat produksinya sebesar 1,29\% dibandingkan 2011, tahun 2013 sedikit meningkat produksinya sebesar $0,42 \%$ dibandingkan 2012 dan tahun 2014 meningkat produksinya sebesar 5,71\% dibandingkan 2013.

\section{Pengelolaan Kilang}

a. Pengelolaan Minyak Mentah, Gas dan lainnya.

Dalam pengelolaan minyak mentah, gas dan lainnya mengalami penurunan selama tiga tahun (2010, 2011, 2012), namun tahun 2013,
2014 terdapat peningkatan.Tahun 2010 terjadi penurunan pengelolaan minyak mentah, gas dan lainnya sebesar 5,06\% diban-dingkan tahun 2009, sedikit penurunan pengelolaannya sebesar $1,78 \%$ pada tahun 2011 dibandingkan 2010, tahun 2012 masih sedikit menurun pengelolaannya sebesar 0,22\% dibandingkan 2011, tahun 2013 meningkat pengelolaannya sebesar 1,92\% dibandingkan 2012 dan tahun 2014 sangat sedikit peningkatannya yaitu $0,12 \%$ dibandingkan 2013.

\section{b. Volume Produksi BBM (10} produk utama)

Volume Produksi BBM (10 produk utama) selama empat tahun (2011 2014) mengalami peningkatan produksi, tetapi tahun 2010 menurun volume produksinya. Tahun 2010 terjadi penurunan volume produksi BBM (10 produk utama) sebesar $5,63 \%$ dibandingkan 2009, tahun 2011 sedikit meningkat produksinya sebesar 0,53\% dibandingkan 2010, tahun 2012 sedikit peningkatan produksinya sebesar $0,73 \%$ dibandingkan 2011, pada tahun 2013 sangat sedikit peningkatannya 
yaitu $0,12 \%$ dibandingkan 2012 dan tahun 2014 masih sedikit meningkat produksinya yaitu 0,89\% dibandingkan 2013.

0,53\% diban-dingkan 2010, tahun 2012 sedikit peningkatan produksinya sebesar $0,73 \%$ dibandingkan 2011, pada tahun 2013 sangat sedikit peningkatannya yaitu $0,12 \%$ dibandingkan 2012 dan tahun 2014 masih sedikit meningkat produksinya yaitu 0,89\% dibandingkan 2013.

\section{c. Volume Produksi Non BBM}

Volume produksi Non BBM mengalami penurunan selama tiga tahun (2010, 2012, 2013), namun meningkat produksinya selama dua tahun (2011, 2014). Pada tahun 2010 terjadi penurunan volume produksi Non BBM sebesar 8,73\% dibandingkan 2009, peningkatan produksinya sebesar $14,87 \%$ pada tahun 2011 dibandingkan 2010, tahun 2012 mengalami penurunan produksi sebesar $6,17 \%$ dibandingkan 2011, pada tahun 2013 masih menurun produksinya yaitu 7,72\% dibandingkan 2012 dan tahun 2014 meningkat produksinya yaitu 2,02\%

dibandingkan 2013.

\section{Distribusi dan Pemasaran}

a. Penjualan BBM (10 produk utama)

Selama tahun 2010 - 2013 terjadi peningkatan penjualan BBM ( 10 produk utama), tetapi pada tahun 2014 mengalami penurunan penjualan BBM. Perkembangannya seperti berikut ini : tahun 2010 meningkat penjualan BBM yaitu 2,19\% dibandingkan 2009, peningkatan penjualan BBM pada tahun 2011 sebesar $8,10 \%$ dibandingkan 2010, tahun 2012 sedikit meningkat penjualannya sebesar 0,43\% dibandingkan 2011, tahun 2013 sedikit meningkat penjualannya sebesar $0,76 \%$ dibandingkan 2012 dan tahun 2014 sedikit menurun penjualan BBM sebesar 0,31\% dibandingkan 2013.

\section{b. Penjualan Domestik Non BBM}

Mulai tahun 2010 - 2014 terjadi peningkatan penjualan domestik Non BBM secara terus-menerus. Terdapat kenaikan penjualan Domestik Non BBM pada tahun 2010 sebesar 14,17\% dibandingkan 
2009, tahun 2011 kenaikan penjualan sebesar $12,94 \%$ dibandingkan 2010, tahun 2012 penjualan meningkat sebesar 11,92\% dibandingkan 2011, tahun 2013 penjualan naik sebesar $6,92 \%$ dibandingkan 2012 dan tahun 2014 penjualan domestik Non BBM meningkat sebesar $11,51 \%$ dibandingkan tahun 2013.

\section{c. Volume Produksi Non BBM}

Volume produksi Non BBM mengalami penurunan selama tiga tahun (2010, 2012, 2013), namun meningkat produksinya selama dua tahun (2011, 2014). Pada tahun 2010 terjadi penurunan volume produksi Non BBM sebesar $8,73 \%$ dibandingkan 2009, peningkatan produksinya sebesar $14,87 \%$ pada tahun 2011 dibandingkan 2010, tahun 2012 mengalami penurunan produksi sebesar $6,17 \%$ dibandingkan 2011, pada tahun 2013 masih menurun produksinya yaitu $7,72 \%$ dibandingkan 2012 dan tahun 2014 meningkat produksinya yaitu $2,02 \%$ dibandingkan 2013.

d. Impor Produk Kilang dan Pembelian Domestik

Selama 5 tahun ini terjadi peningkatan impor produk kilang dan pembelian domestik terusmenerus. Tahun 2010 terdapat peningkatan impor sebesar $33,59 \%$ dibandingkan 2009, tahun 2011 impor meningkat sebesar $19,10 \%$ dibandingkan 2010, tahun 2012 meningkat impornya sebesar $6,47 \%$ dibandingkan 2011, tahun 2013 sedikit meningkat impornya sebesar 1,03\% dibandingkan 2012 dan tahun 2014 meningkat impornya yaitu $2,51 \%$ dibandingkan 2013.

\section{e. Penjualan LNG}

Penjualan LNG terdapat penurunan selama empat tahun (2010, 2011, 2012, 2014), namun tahun 2013 ada peningkatan penjualan LNG, perkembangannya seperti berikut : pada tahun 2010 ada penurunan penjualan LNG sebesar 4,34\% dibandingkan 2009, penurunan penjualan LNG pada tahun 2011 sebesar $15,71 \%$ dibandingkan 2010, tahun 2012 penjualan LNG menurun sebesar 20,08\% dibandingkan 2011, tetapi tahun 2013 penjualan LNG meningkat yaitu 1,80\% dibandingkan 2012 dan tahun 2014 penjualan LNG menurun sebesar $4,44 \%$ dibandingkan 2013. 


\section{Kinerja Keuangan PT Pertamina (Persero)}

Dibawah ini disajikan data mengenai ikhtisar Kinerja Keuangan PT Pertamina (Persero) tahun $2009 \quad-\quad 2014 \quad$ sebagai berikut :

\section{Tabel}

Kinerja Keuangan PT Pertamina (Persero) Tahun 2009 - 2014

\begin{tabular}{|c|c|c|c|c|c|c|}
\hline DESKRIPSI & 2014 & 2013 & 2012 & 2011 & 2010 & 2009 \\
\hline \multicolumn{7}{|l|}{ Laporan Laba-Rugi (Jutaan US\$) } \\
\hline Penjualan \& Pendapatan Usaha lain & 70.648 & 71.102 & 70.924 & 67.297 & 47.559 & 35.135 \\
\hline Beban Pokok Penjualan, BebanUsaha & 66.015 & 66.264 & 66.16 & 61.944 & 44.349 & 32.467 \\
\hline Laba Usaha & 4.633 & 4.838 & 4.764 & 5.353 & 3.210 & 2.668 \\
\hline Penghasilan (beban) lain-lain Bersih & -754 & 195 & 38 & -849 & 89 & 16 \\
\hline Laba Sebelum Beban Pajak Penghasilan & 3.879 & 5.033 & 4.802 & 4.504 & 3.299 & 2.684 \\
\hline Beban Pajak Penghasilan & 2.344 & 1.966 & 2.037 & 2.099 & 1.488 & 1.137 \\
\hline Laba Tahun Berjalan & 1.535 & 3.067 & 2.766 & 2.405 & 1.811 & 1.547 \\
\hline Pendapatan (beban) Komprehensif lain & -23 & -171 & -14 & -7 & 22 & -159 \\
\hline Jumlah Pendapatan Komprehensif & 1.512 & 2.896 & 2.752 & 2.399 & 1.833 & 1.388 \\
\hline \multicolumn{7}{|l|}{ Laba yang dapat Diatribusikan kepada : } \\
\hline Pemilik Entitas Induk & 1.505 & 3.062 & 2.761 & 2.399 & 1.811 & 1.558 \\
\hline Kepentingan Non Pengendali & 30 & 5 & 5 & 6 & 0 & -11 \\
\hline \multicolumn{7}{|l|}{$\begin{array}{l}\text { Jumlah Pendapatan Komprehensif } \\
\text { Diatribusikan : }\end{array}$} \\
\hline Pemilik Entitas Induk & 1.493 & 2.897 & 2.749 & 2.393 & 1.835 & 1.39 \\
\hline Kepentingan Non Pengendali & 19 & -1 & 2 & 6 & -2 & -2 \\
\hline EBITDA & 5.834 & 6.657 & 6.057 & 5.592 & 4.396 & 3.541 \\
\hline \multicolumn{7}{|c|}{$\begin{array}{l}\text { Laporan Neraca/Posisi Keuangan (dalam Jutaan } \\
\text { US\$) }\end{array}$} \\
\hline Aset Lancar & 20.378 & 24.146 & 22.026 & 17.638 & 14.478 & 14.960 \\
\hline Aset Tidak Lancar & 29.950 & 25.196 & 18.933 & 17.286 & 15.527 & 18.544 \\
\hline Total Aset & 50.328 & 49.342 & 40.949 & 34.924 & 30.004 & 33.504 \\
\hline Liabilitas Jangka Pendek & 13.422 & 16.446 & 14.150 & 12.772 & 10.879 & 11.269 \\
\hline Liabilitas Jangka Panjang & 18.870 & 15.607 & 11.616 & 8.869 & 7.358 & 7.215 \\
\hline Total Liabilitas & 32.292 & 32.053 & 25.766 & 21.641 & 18.237 & 18.483 \\
\hline Ekuitas & 18.036 & 17.289 & 15.193 & 13.283 & 11.768 & 15.020 \\
\hline Total Liabilitas dan Ekuitas & 50.328 & 49.342 & 40.959 & 34.924 & 30.004 & 33.504 \\
\hline Modal Kerja Bersih & 6.956 & 7.701 & 7.876 & 4.866 & 3.599 & 3.691 \\
\hline
\end{tabular}


JURNAL M-PROGRESS

\begin{tabular}{|c|c|c|c|c|c|c|c|c|c|}
\hline Total Investasi pada Entitas Asosiasi & 504 & 381 & \multirow{2}{*}{\multicolumn{2}{|c|}{337}} & \multicolumn{2}{|r|}{262} & \multicolumn{2}{|c|}{196} & \multirow[t]{2}{*}{22} \\
\hline \multicolumn{2}{|l|}{$\begin{array}{l}\text { Rasio Keuagan-Keptusan Menteri BUMN } \\
\text { No.100 }\end{array}$} & \multirow[b]{2}{*}{31,88} & & & & & & & \\
\hline ROE (\%) & 16,22 & & \multicolumn{2}{|c|}{30,01} & \multicolumn{2}{|c|}{29,04} & \multicolumn{2}{|c|}{24,05} & 14,9 \\
\hline ROI (\%) & 13,49 & 14,89 & 89 & 6,10 & \multicolumn{2}{|c|}{17,27} & \multicolumn{2}{|c|}{15,91} & 12,9 \\
\hline Rasio Kas (\%) & 29,45 & 29,42 & \multicolumn{2}{|c|}{30,82} & & 6,38 & & 3,22 & 17,9 \\
\hline Rasio Lancar (\%) & 151,82 & 146,82 & \multicolumn{2}{|c|}{155,66} & \multicolumn{2}{|c|}{138,09} & \multicolumn{2}{|c|}{133,09} & 176,1 \\
\hline Total Aset Turn Over (\%) & 164,12 & 159,93 & \multicolumn{2}{|c|}{189,58} & \multicolumn{2}{|c|}{209,68} & \multicolumn{2}{|c|}{173,01} & 129,0 \\
\hline $\begin{array}{l}\text { Total Modal Sendiri terhadap Total Aset } \\
\text { (\%) }\end{array}$ & 33,07 & 30,08 & \multicolumn{2}{|c|}{31,92} & \multicolumn{2}{|c|}{33,14} & \multicolumn{2}{|c|}{34,63} & 20,0 \\
\hline Periode Kolektibilitas (hari) & 37,00 & 43,00 & \multicolumn{2}{|c|}{34,00} & \multicolumn{2}{|c|}{30,00} & \multicolumn{2}{|c|}{29,00} & 47,0 \\
\hline Perputaran Persediaan (hari) & 36,00 & 47,00 & \multicolumn{2}{|c|}{46,00} & & 2,00 & \multicolumn{2}{|c|}{50,00} & 52,0 \\
\hline DESKRIPSI & 2014 & 2013 & 2012 & \multicolumn{2}{|c|}{2011} & 20 & 10 & & 09 \\
\hline Rasio Keuangan & & & & & & & & & \\
\hline Rasio Liabilitas terhadap Ekuitas (\%) & 98,98 & 89,30 & 67,05 & & 15 & & 5,74 & & 27,57 \\
\hline Rasio Liabilitas terhadap Aset (\%) & 35,07 & 31,15 & 24,75 & &, 86 & & 7,83 & & 12,94 \\
\hline Rasio Laba/Rugi terhadap Aset (\%) & 2,99 & 6,16 & 6,70 & &, 87 & & 6,02 & & 4,65 \\
\hline Rasio Laba/Rugi terhadap Pendapatan (\%) & 2,12 & 4,28 & 3,87 & &, 56 & & 3,60 & & 4,44 \\
\hline Kurs Rata-rata US\$/Rp. & $1.878,30$ & $0.451,37$ & $9.380,39$ & 8.77 &, 49 & 9.08 & 4,551 & 10.39 & 98,35 \\
\hline
\end{tabular}

Sumber : Laporan Tahunan PT Pertamina (Persero) Tahun 2009 - 2014. 
Sesuai dengan data tersebut diatas, bisa diuraikan perkembangan kinerja keuangan PT Pertamina (Persero) selama tahun 2009 2014. Kinerja keuangan perusahaan terdiri dari laporan Laba-Rugi, Neraca/Posisi Keuangan dan Rasio Keuangan yang masing-masing akan difokuskan beberapa poin saja. Fokus laporan Laba-Rugi antara lain penjualan dan pendapatan usaha lain, laba usaha, laba sebelum pajak penghasilan dan laba bersih. Fokus Laporan Neraca/Posisi Keuangan yaitu Total Aset, Total Liabilitas, Ekuitas dan Modal Kerja Bersih. Fokus Rasio Keuangan adalah ROE, ROI, Rasio Kas, Rasio Lancar, Perputaran Persediaan, Total Aset Turn Over, Total Modal Sendiri terhadap Total Aset, Rasio Liabilitas terhadap Ekuitas, Rasio Liabilitas terhadap Aset, Rasio Laba (Rugi) terhadap jumlah Aset dan Rasio Laba (Rugi) terhadap Pendapatan.

\section{Fokus Laporan Laba-Rugi}

\section{Penjualan dan Pendapatan Usaha lainnya}

Hasil penjualan dan pendapatan usaha lain PT Pertamina (Persero) yaitu tahun 2009 (35.135 juta USD), 2010 (47.559 juta USD), 2011 (67.297 juta USD), 2012 (70.924 juta USD), 2013 (71.102 juta USD), 2014 (70.648 juta USD).

Dalam penjualan dan pendapatan usaha lainnya terjadi peningkatan selama empat tahun (2010, 2011, 2012, 2013), tetapi tahun 2014 mengalami penurunan. Perkembangannya berikut ini : tahun 2010 terjadi peningkatan hasil penjualan dan pendapatan usaha lain sebesar 35,36\% dibandingkan 2009, tahun 2011 hasil penjualan dan pendapatan lain meningkat sebesar $41,50 \%$ dibandingkan 2010, tahun 2012 penjualan dan pendapatan meningkat sebesar 5,39\% dibandingkan 2011, tahun 2013 penju-alan dan pendapatan lain sedikit peningkatannya yaitu $0,25 \%$ dibandingkan 2012, tahun 2014 sedikit menurun penjualan dan pendapatan lainnya yaitu 0,64\% dibandingkan 2013.

\section{Laba Usaha}

Hasil Laba Usaha PT Pertamina (Persero) adalah tahun 2009 (2.668 juta USD), 2010 (3.210 juta USD), 2011 (5.353 juta USD), 2012 (4.764 juta USD), 2013 (4.838 juta USD), 2014 (4.633 juta USD). Laba usaha mengalami peningkatan selama tiga tahun (2010, 2011, 2013), tetapi selama dua tahun $(2012,2014)$ laba usaha 
menurun. Perkembangannya sebagai berikut : tahun 2010 laba usaha meningkat sebesar 20,31\% dibandingkan 2009, tahun 2011 laba usaha lebih meningkat yaitu $66,76 \%$ dibandingkan 2010, namun laba usaha menurun sebesar $11 \%$ pada tahun 2012 dibandingkan 2011, tahun 2013 laba usaha sedikit meningkat yaitu $1,55 \%$ dibandingkan 2012 dan laba usaha menurun kembali sebesar 4,24\% pada tahun 2014 dibandingkan 2013.

\section{Laba Sebelum Beban Pajak} Penghasilan

PT Pertamina (Persero) memperoleh laba sebelum beban pajak penghasilan : tahun 2009 (2.684 juta USD), 2010 (3.299 juta USD), 2011 (4.504 juta USD), 2012 (4.802 juta USD), 2013 (5.033 juta USD), 2014 (3.879 juta USD). Laba sebelum beban pajak penghasilan selama empat tahun meningkat terus-menerus mulai tahun 2010 - 2013 dan terjadi penurunan pada tahun 2014. Perkembangannya berikut ini, tahun 2010 laba usaha sebelum pajak meningkat sebesar 22,91\% dibandingkan 2009, tahun 2011 lebih meningkat labanya yaitu $36,53 \%$ dibandingkan 2010, laba ini meningkat sebesar 6,62\% pada tahun 2012 dibandingkan 2011, meningkat labanya sebesar 4,81\% pada tahun 2013 dibandingkan 2012 dan tahun 2014 laba ini menurun sebesar 2,93\% dibandingkan 2013.

\section{Laba Bersih}

Laba Bersih PT Pertamina (Persero) selama enam tahun yaitu 2009 (1.547 juta USD), 2010 (1.811 juta USD), 2011 (2.405 juta USD), 2012 (2.766 juta USD), 2013 (3.067 juta USD), 2014 (1.535 juta USD). Laba bersih ini meningkat terus-menerus selama empat tahun $(2010,2011,2012,2013)$, namun laba bersih menurun pada tahun 2014. Perkembangannya berikut ini : laba bersih meningkat sebesar $17,06 \%$ pada tahun 2010 dibandingkan 2009, tahun 2011 laba bersih lebih meningkat sebesar 32,80\% dibandingkan 2010, laba bersih meningkat sebesar $15,01 \%$ pada tahun 2012 dibandingkan 2011, tahun 2013 laba ini meningkat yaitu 10,88\% dibandingkan 2012 tetapi tahun 2014 laba bersih menurun sebesar 49,95\% dibandingkan 2013.

\section{Fokus Laporan Neraca/Posisi Keuangan}

\section{Total Aset}

Total Aset PT Pertamina (Persero) adalah tahun 2009 (33.504 juta USD), 
2010 (30.004 juta USD), 2011 (34.924 juta USD), 2012 (40.959 juta USD), 2013 (49.342 juta USD), 2014 (50.328 juta USD). Pertumbuhan total aset perusahaan berikut ini, tahun 2010 total aset mengalami penurunan $10,45 \%$ dibandingkan 2009, total aset meningkat 16,4\% pada 2011 dibandingkan 2010, total aset meningkat $17,28 \%$ pada 2012 dibandingkan 2011, tahun 2013 total aset meningkat $20,47 \%$ dibandingkan 2012, total aset meningkat $2 \%$ pada 2014 dibandingkan 2013.

\section{Total Liabilitas}

PT Pertamina (Pesero) memiliki total liabilitas yaitu tahun 2009 (18.483 juta USD), 2010

(18.237 juta USD), 2011 (21.641 juta USD), 2012 (25.766 juta USD), 2013 (32.053 juta USD), 2014 (32.292 juta USD). Perkembangan total liabilitas perusahaan adalah tahun 2010 total liabilitas mengalami penurunan sebesar $1,33 \%$ dibandingkan 2009, total liabilitas meningkat $18,66 \%$ pada 2011 dibandingkan 2010, total liabilitas meningkat $19,06 \%$ pada 2012 dibandingkan 2011, total liabilitas meningkat $24,4 \%$ pada 2013 dibandingkan 2012, total aset meningkat 0,7\% pada 2014 dibandingkan 2013.

\section{Ekuitas}

Ekuitas yang dimiliki PT Pertamina (Persero) yaitu tahun 2009 (15.020 juta USD), 2010 (11.768 juta USD), 2011 (13.283 juta USD), 2012 (15.193 juta USD), 2013 (17.289 juta USD), 2014 (18.036 juta USD). Pertumbuhan ekuitas perusahaan adalah tahun 2010 ekuitas perusahaan mengalami penurunan 21,65\% dibandingkan 2009, tahun 2011 ekuitas naik sebesar 12,87\% dibandingkan 2010, ekuitas naik 14,38\% pada 2012 dibandingkan 2011, ekuitas naik 13,8\% pada 2013 dibandingkan 2012, ekuitas meningkat 4,32\% pada 2014 dibandingkan 2013.

\section{Modal Kerja Bersih}

Modal kerja besih yaitu menunjukkan besarnya dana yang tersedia untuk membiayai kegiatan sehari-hari. PT Pertamina (Persero) memiliki modal kerja bersih yaitu tahun 2009 (3.691 juta USD), 2010 (3.599 juta USD), 2011 (4.866 juta USD), 2012 (7.876 juta USD), 2013 (7.701 juta USD), 2014 (6.956 juta USD). Peningkatan dan penurunan modal kerja bersih 
perusahaan berikut ini : 2010 modal kerja bersih mengalami penurunan 2,49\% dibandingkan 2009, modal kerja bersih meningkat 35,2\% pada 2011 dibandingkan 2010, modal kerja bersih meningkat $61,86 \%$ pada 2012 dibandingkan 2011, modal kerja bersih 2013 meningkat 2,22\% dibandingkan 2012, modal kerja bersih 2014 meningkat 9,67\% dibandingkan 2013.

\section{Rasio Keuangan - Keputusan Menteri BUMN No. 100}

Rasio Keuangan sebagai alat yang digunakan dalam pemeriksaan terhadap kesehatan keuangan perusahaan.Hal ini untuk mengevaluasi kondisi keuangan dan kinerja perusahaan.Perhitungan rasio-rasio keuangan ini dilakukan untuk memperoleh perbandingan yang dapat lebih berguna dibandingkan dengan angka-angka yang berdiri sendiri.Rasio Keuangan terdiri dari lima jenis utama yaitu likuiditas, pengungkit (hutang), pencakupan, aktivitas dan profitabilitas. Adapun hasil rasio keuangan PT Pertamina (Persero) yang merujuk keputusan Menteri BUMN No.100 sebagai berikut :

\section{Fokus Rasio Keuangan}

\section{ROE (Return on Equity)}

ROE menunjukkan efektivitas manajemen dalam menghasilkan laba dari total ekuitas yang digunakan. Hasil ROE PT Pertamina (Persero) yaitu tahun 2009 (14,92\%), 2010 (24,05\%), 2011 (29,04\%), $2012 \quad(30,01 \%), \quad 2013$ (31,88\%), $2014 \quad(16,22 \%)$. Perkembangan ROE perusahaan : tahun 2010 ROE meningkat cukup besar yaitu 61,19\% dibanding 2009, tahun 2011 ROE meningkat sebesar 20,75\% dibandingkan 2010, ROE naik sebesar 3,34\% pada tahun 2012 dibandingkan 2011, ROE naik sebesar 6,23\% pada tahun 2013 dibandingkan 2012, tetapi ROE mengalami penurunan 49,12\% pada tahun 2014 dibandingkan tahun 2013.

\section{ROI (Return on Investment)}

ROI yaitu mengukur hasil yang diperoleh pemegang saham dan merupakan salah satu rasio yang komprehensif baik dalam lingkupnya (laba bersih) maupun dalam kemanfaatannya (pemegang saham). ROI, menunjukkan hasil bagi investor, dalam hal ini pemerintah Republik Indonesia sebagai satu-satunya investor, $100 \%$ pemegang saham PT Pertamina 
(Persero). Hasil ROI PT Pertamina (Persero) adalah tahun 2009 (12,90\%), 2010 (15,91\%), 2011 (17,27\%), 2012 (16,10\%), $2013 \quad$ (14,89\%), 2014 $(13,49 \%)$. Pertumbuhan ROI sebagai berikut : tahun 2010 hasil ROI mengalami kenaikan sebesar 23,33\% dibandingkan 2009, ROI meningkat sebesar 8,55\% pada tahun 2011 dibandingkan 2010, tetapi ROI menurun sebesar 6,77\% pada tahun 2012 dibandingkan 2011, tahun 2013 ROI menurun sebesar $7,52 \%$ dibandingkan 2012 dan tahun 2014 ROI mangalami penurunan yaitu $9,4 \%$ dibandingkan 2013.

\section{Rasio Kas (Cash Ratio)}

Rasio Kas, menunjukkan ukuran kecukupan kekayaan (dana) kas yang likuid untuk memenuhi transaksi, kewajiban lancar yang segera dibayar. Hasil Rasio Kas PT Pertamina (Persero) yaitu tahun 2009 (17,92\%), 2010 (23,22\%), $2011 \quad(26,38 \%), \quad 2012$ (30,82\%), $2013 \quad(29,42 \%), \quad 2014$ $(29,45 \%)$. Perkembangan Rasio Kas berikut ini : 2010 hasil rasio kas naik sebesar 29,58\% dibandingkan 2009, rasio kas naik sebesar $13,61 \%$ pada tahun 2011 dibandingkan 2010, tahun 2012 rasio kas meningkat sebesar $16,83 \%$ dibandingkan tahun 2011, namun tahun 2013 rasio kas menurun yaitu 4,54\% dibandingkan tahun 2012 dan tahun 2014 rasio kas sangat sedikit naik yaitu $0,1 \%$ dibandingkan 2013 .

\section{Rasio Lancar(Current Ratio)}

Rasio Lancar, menunjukkan ukuran kecukupan kekayaan likuid untuk memenuhi utang lancar yang harus segera dibayar. Hasil Rasio Lancar PT Pertamina (Persero) yaitu tahun 2009 (176,15\%), $2010 \quad(133,09 \%), \quad 2011$ (138,09\%), $2012 \quad(155,66 \%), \quad 2013$ (146,42\%), $2014 \quad(151,82 \%)$. Pertumbuhan Rasio Lancar berikut ini : tahun 2010 Rasio Lancar menurun sebesar 24,45\% dibandingkan 2009, rasio lancar naik sebesar $3,76 \%$ pada tahun 2011 dibandingkan 2010, rasio lancar meningkat $12,72 \%$ pada tahun 2012 dibanding-kan 2011, tahun 2013 rasio lancar menurun 5,94\% dibandingkan 2012 dan tahun 2014 rasio lancar naik sebesar 3,69\% dibandingkan 2013.

5. Perputaran Persediaan (inventory turnover) 
Perputaran persediaan menunjukkan kecepatan perputaran persediaan barang untuk mengha-silkan penjualan. Semakin tinggi angka perputaran berarti makin sedikit waktu yang diperlukan untuk suatu barang berada dalam persediaan dan makin cepat terjual.

PT Pertamina (Persero) memiliki perputaran persediaan berikut ini : tahun 2009 (52 hari), 2010 (50 hari), 2011 (42 hari), 2012 (46 hari), 2013 (47 hari), 2014 (36 hari). Perkembangan perputaran persediaan perusahaan yaitu tahun 2010 mengalami penurunan $3,85 \%$ dibandingkan 2009, perputaran persediaan menurun $16 \%$ pada tahun 2011 dibandingkan 2010, perputaran persediaan meningkat $9,52 \%$ pada tahun 2012 dibandingkan 2011, 2013 perputaran persediaan meningkat $2,17 \%$ dibandingkan 2012, perputaran persediaan meningkat $23,4 \%$ pada tahun 2014 dibandingkan 2013.

\section{Total Asset Turn Over (Perputaran Aktiva Total)}

Perputaran Aktiva Total yaitu menunjukkan bagaiman efisiensi penggunaan aktiva untuk menghasilkan penjualan. Hasil perputaran aktiva total
PT Pertamina (Persero) : tahun 2009 (129,09\%), 2010 (173,01\%), 2011 (209,68\%), 2012 (189,58\%), 2013 (159,93\%), $2014 \quad(164,12 \%)$. Pertumbuhan perputaran aktiva total yaitu tahun 2010 hasil perputaran aktiva total meningkat sebesar 34,02\% dibandingkan 2009, tahun 2011 meningkat sebesar 21,19\% dibandingkan 2010, tetapi menurun sebesar 9,59\% pada tahun 2012 dibandingkan 2011, tahun 2013 menurun 15,64\% dibandingkan 2012 dan meningkat sebesar $2,62 \%$ pada tahun 2014 dibandingkan 2013.

\section{Total Modal Sendiri Terhadap Aset} (Total of Equity to Total Asset)

PT Pertamina (Persero) memiliki hasil rasio total modal sendiri terhadap aset : tahun 2009 (20,06\%), 2010 (34,63\%), 2011 (33,14\%), 2012 (31,92\%), 2013 (30,08\%), $2014(33,07 \%)$.

Perkembangan rasio total moal sendiri terhadap asset : tahun 2010 rasio total modal sendiri terhadap aset meningkat sebesar $72,63 \%$ dibandingkan 2009, tahun 2011 terjadi penurunan yaitu 4,3\% dibandingkan 2010, rasio ini menurun sebesar $3,68 \%$ pada tahun 2012 dibandingkan 2011, tahun 2013 rasio ini 
menurun yaitu $5,76 \%$ dibandingkan 2012 tetapi tahun 2014 rasio ini meningkat sebesar 9,94\% dibandingkan 2013.

\section{Rasio Liabilitas terhadap Ekuitas(Debt to Equity Ratio)}

Rasio Liabilitas terhadap Ekuitas yaitu mengukur jumlah relatif dari dana yang berasal dari pinjaman terhadap modal sendiri. Hasil Rasio Liabilitas terhadap Ekuitas PT Pertamina (Persero) yaitu tahun 2009 (27,57\%), 2010 (45,74\%), 2011 (55,15\%), 2012 (67,05\%), 2013 (89,30\%), 2014 (98,98\%). Pertumbuhan rasio liabilitas terhadap ekuitas sebagai berikut : tahun 2010 rasio liabilitas terhadap ekuitas meningkat sebesar $65,9 \%$ dibandingkan 2009, rasio ini meningkat yaitu $20,57 \%$ pada tahun 2011 dibandingkan 2010, tahun 2012 rasio ini meningkat yaitu $21,58 \%$ dibandingkan tahun 2011, terjadi peningkatan rasio ini sebesar 33,18\% pada tahun 2013 dibandingkan 2012 dan tahun 2014 rasio liabilitas terhadap ekuitas meningkat 10,84\% dibandingkan tahun 2013.

\section{Rasio Liabilitas terhadap Aset (Debt to Assets Ratio)}

Rasio Liabilitas terhadap Aset yaitu menunjukkan mengukur jumlah relatif dari dana yang berasal dari utang terhadap aset. Selama enam tahun hasil rasio liabilitas terhadap aset PT Pertamina (Persero) : tahun 2009 (12,94\%), $2010 \quad(17,83 \%), \quad 2011$ (20,86\%), $2012 \quad(24,75 \%), \quad 2013$ (31,15\%), 2014 (35,07\%). Pertumbuhan rasio ini sebagai berikut : terjadi peningkatan rasio liabilitas terhadap aset sebesar $37,79 \%$ pada tahun 2010 dibandingkan 2009, rasio ini meningkat 16,99\% pada tahun 2011 dibandingkan 2010, tahun 2012 rasio liabilitas terhadap aset naik sebesar 18,65\% dibandingkan 2011, tahun 2013 rasio ini meningkat 25,86\% dibandingkan 2012 dan tahun 2014 rasio ini naik sebesar 12,58\% dibandingkan 2013.

\section{Rasio Laba (Rugi) terhadap Jumlah Aset (Return On Asset/ROA)}

Rasio Laba (Rugi) terhadap Jumlah Aset yaitu menunjukkan efektivitas manajemen dalam menghasilkan laba dari jumlah aktiva yang digunakan. Hasil rasio laba-rugi terhadap jumlah aset PT Pertamina (Persero) yaitu tahun 2009 (4,65\%), 2010 (6,02\%), 2011 
(6,87\%), 2012 (6,70\%), 2013 (6,16\%), 2014 (2,99\%). Perkembangan ROA berikut ini : tahun 2010 ROA meningkat sebesar 29,46\% dibandingkan 2009, tahun 2011 ROA meningkat 14,12\% dibandingkan 2010, tahun 2012 ROA menurun 2,47\% dibandingkan 2011, tahun 2013 ROA menurun sebesar 8,06\% dibandingkan 2012 dan tahun 2014 ROA menurun drastis sebesar 51,46\% dibandingkan 2013.

\section{Rasio Laba (Rugi) terhadap Pendapatan}

Rasio Laba (Rugi) terhadap Pendapatan yang menunjukkan efektivitas manajemen dalam menghasilkan laba perusahaan terhadap penjualan dan pendapatan lainnya. Hasil rasio labarugi terhadap pendapatan PT Pertamina (Persero) yaitu tahun 2009 (4,44\%), 2010 (3,80\%), 2011 (3,56\%), 2012 (3,87\%), 2013 (4,28\%), 2014 (2,12\%). Perkembangan rasio laba (rugi) terhadap pendapatan pada tahun 2010 menurun sebesar $14,41 \%$ dibanding-kan 2009, rasio ini menurun sebesar $6,32 \%$ pada tahun 2011 dibandingkan 2010, tetapi rasio ini meningkat sebesar $8,71 \%$ pada tahun 2012 dibandingkan 2011, tahun
2013 rasio ini meningkat yaitu 10,59\% dibandingkan 2012, namun tahun 2014 rasio ini mengalami penurunan secara drastis sebesar $50,47 \%$ dibandingkan 2013.

\section{PENUTUP}

PT Pertamina (Persero) terus berupaya meningkatkan hasil kinerjanya baik kinerja operasional maupun kinerja keuangan melalui strategi "aggressive upstream, profitable downstream“. Pertamina sebagai perusahaan kelas dunia, mengelola tantangan menjadi sebuah kesempatan, juga menerapkan strategi efisiensi dan optimalisasi produksi. Disisi lain, kinerja yang optimal terus dikembangkan, sejalan dengan penguatan kinerja tata kelola perusahaan yang baik (good corporate governance/GCG). Naiknya produksi minyak mentah dan akuisisi aset Murphy Oil Corp. di Malaysia merupakan salah satu pencapaian yang baik tahun 2014. Selain itu, Pertamina diakui oleh Komisi Pemberantasan Korupsi (KPK) telah berhasil mengendalikan gratifikasi, sehingga langkah perusahaan akan semakin cepat. Pertamina mengangkat tema "Inspiring Indonesia to the World" pada Laporan Tahunan 2014 untuk mengiringi 
laju pergerakan isu energi global dan berbagi inspirasi sebagai penyedia energi. Pertamina sudah memiliki sertifikasi nasional dan internasional sebagai dasar melaksanakan operasinya dan juga menerima banyak penghargaan baik nasional maupun internasional sebagai pengakuan prestasinya yang mendunia.

$$
\text { Kinerja Keuangan dan Kinerja }
$$

Operasional Pertamina cukup memuaskan, meskipun masih ada pencapaian yang belum sesuai harapan. Secara keseluruhan perkembangan Kinerja Keuangan dan Kinerja Operasi PT Pertamina (Persero) cenderung meningkat selama tahun 2009 2014. Selanjutnya hasil analisis ini akan menjadi acuan untuk lebih meningkatkan capaian yang lebih baik pada tahun 2015 dan masa mendatang.

\section{DAFTAR PUSTAKA}

Auerbach, Robert D.; Money, Banking and Financial Markets, Third Edition, Macmillan Publishing Co., New York - USA, 1989.

Eitman, David K, et al; Multinational Business Finance, $8^{\text {th }}$ Edition, Addison-Wesley Publishing Co.,California-USA,1998.

Eitman, David K, et al; Multinational Business Finance, $9^{\text {th }}$ Edition,
Addison-Wesley Co.,California - USA, 2001.

Publishing

Eiteman, David K., et.al., Multinational Business Finance, Book $1^{\text {st }}$ and $2^{\text {nd }}$, $9^{\text {th }}$ edition, Addison-Wesley Publishing Co.,Inc., New Jersey, 2005.

Fabozzi, Frank J.; Investment Management, Prentice Hall, Inc.A.Simon \& Schusterr Co., New Jersey-USA, 1995.

Libby, Robert et. al; Financial Accounting, $2^{\text {nd }}$ ed., McGraw-Hill Co., New York - USA, 1998.

Martono and D. Agus Harjito; Financial Management, $1^{\text {st }}$ ed., Ekonisia-FE UII, Yogyakarta-Indonesia, 2007.

Miller, Roger LeRoy and Pulsinelli, Robert W.; Modern Money and Banking, Second Edition, McGraw-Hill Book Company,New York - USA, 1989.

Mudrajad Kuncoro; International Financial Management, $1^{\text {st }}$ ed., BPFEYogyakarta Indonesia, 1997.

PT. Pertamina (Persero); Laporan Tahunan 2009 - 2014, Pertamina, Jakarta, $2009-2014$.

Reilly, Frank K. and Brown, Keith C.; Investment Analysis and Portofolio Management, Fifth Edition, The Dryden Press, Philadelphia-USA, 1997.

Salvatore, Dominick; International Economics,Book $2^{\text {nd }}$, $9^{\text {th }}$ edition, John Wiley\& Sons, Inc., New York, USA, 2007. 
Sentanoe Kertonegoro, Analisa dan Manajemen Investasi, Widya Press, Jakarta, 2005.

Sharpe, William F. et al; Investment, $5^{\text {th }}$ ed., Prentice Hall, Inc. New Jersey USA, 1995.

Sharpe, William F. et al; Investment, Book $1^{\text {th }}$ and $2^{\text {nd }}$, Prentice Hall(Singapore) Pte.Ltd., 1997.

Sri Handaru Yuliati and Handoyo Prasetyo; International Financial Management, $1^{\text {st }}$ ed., Andi Publisher, Yogyakarta-Indonesia, 1998.

Suad Husan; Financial Management, Book $1^{\text {th }}$ and $2^{\text {nd }}, 4^{\text {th }}$ ed., BPFEYogyakarta Indonesia, 1997.

Van Horne, James C. and Wachowicz, Jr. John M.; Princip of Financial Management, $9^{\text {th }}$ ed., Prentice Hall Inc., New Jersey - USA, 1995.

Van Horne, James C.and Wachowicz, Jr. John M.; Financial Managementand Policy, Eleventh-International Edition, Prentice Hall Inc., New Jersey-USA, 1998. 